DEPÓSITO LEGAL ZU2020000153

Esta publicación científica en formato digital

es continuidad de la revista impresa

ISSN 0041-8811

E-ISSN 2665-0428

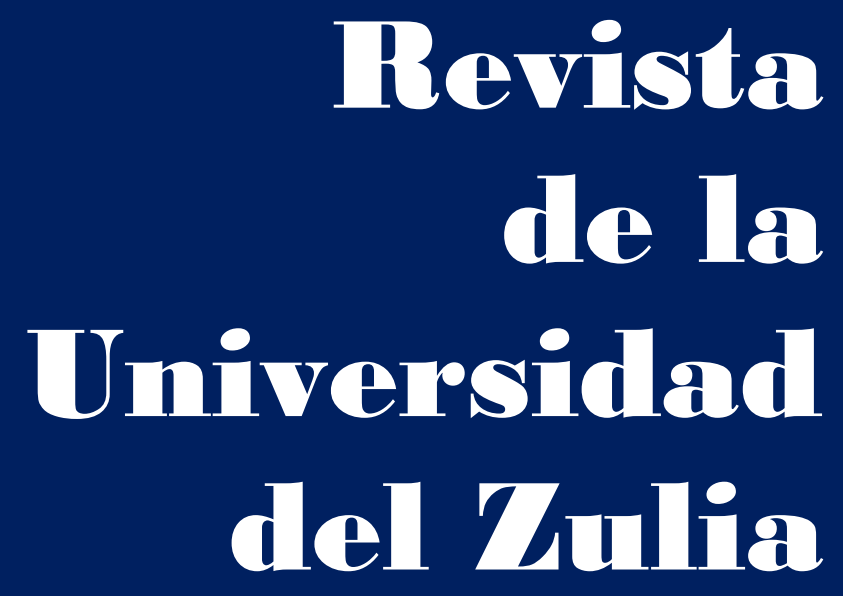

Fundada en 1947

por el Dr. Jesús Emrique Lossada

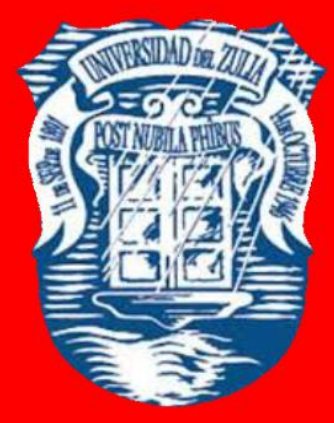

Ciencias

Sociales

y Arte

Año $12 \quad N^{\circ} 34$

Septiembre - Diciembre 2021

Tercera Época

Maracaibo-Veneruela 


\title{
Gender differences in solo entrepreneurship in modern countries
}

\author{
Iuliia Pinkovetskaia * \\ Natalia Neif ** \\ Aleksandra Navasardyan *** \\ Tatyana Treskova **** \\ Marina Yashina $* * * *$
}

ABSTRACT

Aim of the study is to evaluate the indicators describing the level of solo entrepreneurship among women and men who are beginning entrepreneurs in different countries. Empirical data provided in the Global Entrepreneurship Monitoring Project for fifty-nine countries were used as initial information in calculations. Economic and mathematical modeling was based on development of density functions normal distribution. In the study, three indicators describing solo entrepreneurship in 59 countries were evaluated: share of solo entrepreneurs-women in the total number of women who participate in the creation of their own businesses in different countries; share of solo entrepreneurs-men in total number of men who participate in creation of their own businesses in different countries; ratio of the above-mentioned shares of solo entrepreneurs of women and men. Average values and ranges of changes in considered indicators were determined, which are typical for most countries. In addition, national economies that are characterized by high and low values of each of the three indicators were identified. The study showed that there is a gender gap in the values of indicators in most countries. It is proved that share of women involved in solo entrepreneurship in most countries is higher than that of men.

KEYWORDS: Entrepreneurs; women; men; gender roles; self employed; business management; mathematical models.

*Department of Economic Analysis and State Management, Ulyanovsk State University, Ulyanovsk, 432000, Russia. ORCID: http://orcid.org/0000-0002-8224-9031. E-mail: pinkovetskaia@gmail.com

** Department of Finance and Credit. Ulyanovsk State Agrarian University named after P. A. Stolypin, Ulyanovsk, 432017, Russia. ORCID: http://orcid.org/0000-0002-2758-6684.

*** Department of Economic Security, Accounting and Audit, Ulyanovsk State Agrarian University named after P. A. Stolypin, Ulyanovsk, 432017, Russia. ORCID: http:/orcid.org/0000-0003-0129-7099.

**** Department of Finance and Credit, Ulyanovsk State Agrarian University named after P. A. Stolypin, Ulyanovsk, 432017, Russia. ORCID: http://orcid.org/0000-0001-7478-0095.

Department of Finance and Credit, Ulyanovsk State Agrarian University named after P. A. Stolypin, Ulyanovsk, 432017, Russia. ORCID: http://orcid.org/0000-0002-7133-1793. 


\section{Diferencias de género en el emprendimiento individual en los países modernos}

RESUMEN

El objetivo del estudio es evaluar los indicadores que caracterizan el nivel de emprendimiento individual entre mujeres y hombres que son emprendedores en ciernes en diferentes países. Los cálculos se basaron en datos empíricos presentados en el marco del Proyecto Mundial de Vigilancia de la Empresa para cincuenta y nueve países. El modelado económico-matemático se basó en el desarrollo de funciones de densidad de distribución normal. En el estudio se evaluaron tres indicadores que caracterizaban a las empresas por cuenta propia en 59 países: la proporción de mujeres empresarias por cuenta propia en el número total de mujeres que participan en la creación de empresas por cuenta propia en diferentes países; la proporción de hombres empresarios por cuenta propia en el número total de hombres que participan en la creación de empresas por cuenta propia en diferentes países; y la proporción de mujeres y hombres empresarios por cuenta propia. Se determinaron los promedios y los rangos de variación de los indicadores examinados, que son comunes en la mayoría de los países. Además, se identificaron las economías nacionales que se caracterizan por valores altos y bajos de cada uno de los tres indicadores. El estudio reveló que en la mayoría de los países hay diferencias de género en los valores de los indicadores. Se ha demostrado que la proporción de mujeres que trabajan por cuenta propia es mayor en la mayoría de los países que en los hombres.

PALABRAS CLAVE: Emprendedores; mujeres; hombres; roles de género; trabajador por cuenta propia; gestión empresarial; modelos matemáticos.

\section{Introduction}

Entrepreneurship is considered in most national economies as the main direction of their development, providing not only an increase in the volume of production of goods and services, but also using innovation, increasing efficiency, creating the prerequisites for structural transformations, reducing the unemployment rate (Lee \& Rodnguez-Pose, 2021; Schneck, 2020; Szerb et al., 2019). As you know, there are two main organizational and legal forms of entrepreneurial activity, namely solo entrepreneurs and legal entities. Our study focused on solo entrepreneurship, which has developed significantly in recent years (Mababu \& Merino-Hijosa, 2015; Pinkovetskaia et al., 2020; Toivanen et al., 2015). Even in the context of the 2020-2021 pandemic, solo entrepreneurs in most industries continued their activities, often remotely. 
Solo entrepreneurs not only earn money (Ruzzier \& Konecnik Ruzzier, 2015), but also produce goods, provide services, that is, increase national wealth, and create jobs. It is important that this form of entrepreneurship reflects work preferences and creates an effective, work-life balance, ensuring the social well-being of entrepreneurs (Gottschalk \& Niefert, 2013; Gudmunson et al., 2009). Often, solo entrepreneurship acts as a side business that supports a person working elsewhere.

Solo entrepreneurship provides flexibility, allowing the solo to work when and where it is most convenient, to work part-time, and to fill temporary employment gaps (Mababu, 2009). Solo entrepreneurs have a high degree of freedom and independence (Van Gelderen \& Jansen, 2006). Solo entrepreneurship is characterized by low barriers to entry, it does not require significant initial capital, experience in managing firms with a large number of employees, and a number of other competence, that characterize firms (Vries et al., 2020).

Our article makes two main contributions to the existing knowledge about the level of development of solo entrepreneurship. First, the prevalence of solo entrepreneurs in modern countries is considered, that is, it is determined how often entrepreneurs conduct activities without the formation of legal entities. At the same time, the corresponding indicators are studied not for one, but for a large number of countries. The second contribution is related to the analysis of the gender aspects of solo entrepreneurship. That is, the study of the features of such activities of women and men. In addition, it is logical, in our opinion, to determine whether there are gender differences in the behavior of women and men involved in the process of creating their own businesses without the formation of legal entities. It should be noted that the study of the gender characteristics of solo entrepreneurship has not been given sufficient attention in scientific publications to date.

The purpose of the article is to evaluate the indicators describing the level of solo entrepreneurship in the total number of women and men who are beginning entrepreneurs in different countries. Our article responds to calls for a more in-depth study of the development of solo entrepreneurship, which according to a number of authors (Hipp et al., 2015; Holloway \& Pimlott-Wilson, 2021; Bogenhold, 2019) is an insufficiently studied type of entrepreneurship. In addition, the article responds to calls for the study of the gender dimensions of solo entrepreneurship (Mababu \& Merino-Hijosa, 2015). 


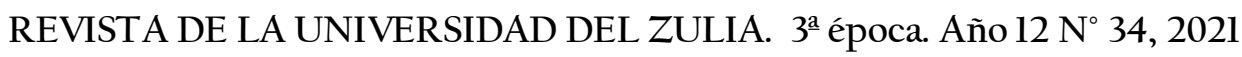

Iuliia Pinkovetskaia et al// Gender differences in solo entrepreneurship in modern countries, 224-238 DOI: $\underline{\text { http://dx.doi.org/10.46925//rdluz.34.14 }}$

In our research, we answer the following questions:

1. What is the share of women solo entrepreneurs in the total number of women who are involved in setting up their own businesses in different countries?

2. What is the share of men solo entrepreneurs in the total number of men who are involved in setting up their own businesses in different countries?

3. Was there a gender gap in the proportion of solo entrepreneurs of women and men who participate in the creation of their own businesses in different countries?

\section{Literature review}

The relevance of the study of solo entrepreneurship is emphasized in many scientific studies carried out in recent years. The following works are of the greatest interest among them.

As shown in the article (Boeri et al., 2020), the structure of entrepreneurship in most Organisation for Economic Co-operation and Development (OECD) countries has changed over the past 20 years, with the share of solo entrepreneurs increasing. They account for between 4 and 22 per cent of the economically active population in OECD countries. Similar conclusions about the growth of the share of entrepreneurs working without the formation of legal entities, on the example of the United States, are made in the works (Katz \& Krueger, 2018; Abraham \& Amaya, 2019). There were almost four million solo entrepreneurs in the UK by the end of 2019 (Giupponi $\&$ Xu, 2020). It should be noted that the share of solo entrepreneurs in the UK according to these authors increased from 11.5\% to $14.1 \%$ in the period $2000-2017$.

The study (Dvoulety et al., 2019) shows the positive role of solo entrepreneurship on the example of the Visegrad countries (Czech Republic, Hungary, Poland and Slovakia). It is proved that solo entrepreneurs who do not attract labor earn an average of $6.7 \%$ more than employees. The paper (Van Stel et al., 2020) examines the peculiarities of the activities of solo entrepreneurs with higher education and their reluctance to use employees. The article (Box \& Segerlind, 2018) examines the creation of new businesses on the example of Sweden. The study (Koe, 2016) describes the activities of solo entrepreneurs in Malaysia. The article (Schummer et al., 2019) examines various options for entrepreneurs to set up their own businesses in Germany and concludes that many of them prefer to be solo entrepreneurs. 
A number of studies (e.g., Fritsch \& Wyrwich, 2014; Millan et al., 2012) highlight the differences between individual entrepreneurship in various countries. It should be noted, that solo entrepreneurship is carried out by citizens of different countries at their own request and in the presence of appropriate opportunities.

Gender characteristics of entrepreneurship in the United States are analyzed in the article (Yang et al., 2017). The gender differentiation of new businesses created in Germany is studied in the article (Gottschalk \& Niefert, 2013). Using the example of the European Union countries, it was shown that there are gender differences between solo entrepreneurs (Cowling, 2000). Based on the analysis of data for the period 1997-2014 for 32 European countries, the article (Van Stel \& Van der Zwan, 2020) suggests the predominance of highly educated women in solo entrepreneurship.

\section{Methodology and design}

The study used the results of surveys of entrepreneurs aged 18-64 years, conducted in 59 countries, during the implementation of the Global Entrepreneurship Monitoring Project (2019). The report on this project included information on two rounds of the survey of respondents: in 10 countries, entrepreneurs were interviewed in 2017, and in 49 countries - in 2018. In each of the countries, responses were received from at least two thousand respondents, including men and women. The total number of respondents in all countries exceeded 120,000 entrepreneurs. The countries in which the survey was conducted differed in terms of the level of income of the population. According to the World Bank classification, 32 countries had high incomes, 17 countries had average incomes, and 10 countries had low incomes. The geographical location of the countries is as follows: Europe - 22 countries, Asia - 17 countries, Latin America - 11 countries, Africa - 6 countries, North America - 2 countries and Australia. The countries where the survey of entrepreneurs was conducted included all the largest economies in the world, as well as other countries. During the surveys, entrepreneurs answered, in particular, the question of whether they are solo entrepreneurs. These surveys provided information on the proportion of solo entrepreneurs of women and men in the total number of relevant gender groups. The share of solo entrepreneurs was defined as the ratio of entrepreneurs who indicated during the survey that they did not create legal entities to the total number of entrepreneurs surveyed for each of the countries. 
The study included five stages. At the first stage, the form ation of empirical data sets describing the specific weights of women and men belonging to solo entrepreneurs in the total number involved in the creation of their own business was carried out. At the second stage, the formation of arrays of empirical data describing the ratio of the specified specific weights of women and men related to solo entrepreneurs was carried out. At the third stage, the distribution of the values of indicators characterizing the share of solo entrepreneurs of women and men in the total number involved in the creation of their own business by country was determined. At the fourth stage, the countries that are characterized by high and low levels of the considered indicators were identified. At the same time, both the territorial location of such countries and the average income of the population in them were taken into account. On the fifth stage was carried out comparative analysis of level development solo entrepreneurship in Russia and other countries.

Our study examined the evaluation of three indicators that characterize the gender aspects of early solo entrepreneurship in 59 countries:

- the share of solo entrepreneurs-women in the total number of women who participate in the creation of their own businesses in different countries;

- the share of solo men entrepreneurs in the total number of men who participate in the creation of their own businesses in different countries;

- the ratio of the above-mentioned shares of solo entrepreneurs of women and men.

Our study included testing the following three hypotheses:

- hypothesis 1 - the values of the three indicators under consideration have a significant differentiation between different countries;

- hypothesis 2 - the geographical location of countries does not significantly affect the values of each of the three indicators;

hypothesis 3 - the level of income of the population in the countries under consideration does not significantly affect the values of each of the three indicators.

The estimation of the values of the three indicators under consideration was based on the economic and mathematical modeling of the initial empirical data. As models, we used the density functions of the normal distribution, the method of development of which for estimating the values of specific indicators was proposed by the author. Some aspects of the use of the technique are given in the author's works (for example, Pinkovetskaia et al., 
2021). Note that in the process of developing the functions, the initial empirical data were grouped according to the ranges of changes in the values of the indicators. These data groups can be geometrically represented as corresponding histograms. Data approximation using normal distribution functions was performed using generally accepted statistical methods. It is important to note that the average value of the considered indicators, as well as their standard deviations for the density functions of the normal distribution, were displayed in the formulas of the developed functions themselves. Therefore, having constructed a specific function, we get the specified parameters of the considered indicators without additional calculations.

The obtained functions allowed us to determine the average values of each of the three indicators for the countries under consideration, as well as the ranges of their variation that are typical for most countries. In addition, the study identified countries in which the indicators under consideration have values higher than the upper and lower than the lower limits of the ranges. The boundaries of the indicator ranges for $68 \%$ of the countries were determined based on the average values of the indicators and the corresponding standard deviations. The lower bound of the interval is equal to the difference between the mean and the standard deviation, and the upper bound is equal to their sum.

\section{Results and discussion}

In the course of the computational experiment, economic and mathematical modeling was carried out on the basis of empirical data. The models that describe the distribution of the three indicators across all 59 countries are shown below:

- the share of solo entrepreneurs of women in the total number of women who participate in the creation of their own businesses

$$
y_{1}\left(x_{1}\right)=\frac{7.01}{0.19 \times \sqrt{2 \pi}} \cdot e^{\frac{-\left(x_{1}-0.33\right)^{2}}{2 \times 0.19 \times 0.19}}
$$

- the share of solo men entrepreneurs in the total number of men who participate in the creation of their own businesses in different countries

$$
y_{2}\left(x_{2}\right)=\frac{6.38}{0.15 \times \sqrt{2 \pi}} \cdot e^{\frac{-\left(x_{2}-0.27\right)^{2}}{2 \times 0.15 \times 0.15}} ;
$$


- the ratio of the values of indicators for solo entrepreneurs to women and men

$$
y_{3}\left(x_{3}\right)=\frac{21.53}{0.62 \times \sqrt{2 \pi}} \cdot e^{\frac{-\left(x_{3}-1.38\right)^{2}}{2 \times 0.62 \times 0.62}} .
$$

The quality of functions (1)-(3) we tested using such criteria: the Kolmogorov-Smirnov, the Pearson and the Shapiro-Wilk. Calculated values of criteria are given in Table 1.

Table 1. Calculated values of criteria

\begin{tabular}{|c|c|c|c|}
\hline \multirow{2}{*}{ Indicators } & \multicolumn{2}{|c|}{ Criteria } \\
\cline { 2 - 4 } & $\begin{array}{c}\text { The } \\
\text { Kolmogorov- } \\
\text { Smirnov test }\end{array}$ & $\begin{array}{c}\text { The } \\
\text { Pearson } \\
\text { test }\end{array}$ & $\begin{array}{c}\text { The } \\
\text { Shapiro } \\
\text {-Wilk } \\
\text { test }\end{array}$ \\
\hline $\begin{array}{c}\text { The share of solo entrepreneurs of women } \\
\text { in the total number of women who } \\
\text { participate in the creation of their own } \\
\text { businesses }\end{array}$ & 0.05 & 1.54 & 0.98 \\
\hline $\begin{array}{c}\text { The share of solo men entrepreneurs in } \\
\text { the total number of men who participate } \\
\text { in the creation of their own businesses in } \\
\text { different countries }\end{array}$ & 0.06 & 1.91 & 0.97 \\
\hline $\begin{array}{c}\text { The ratio of the values of indicators for } \\
\text { solo entrepreneurs to women and men }\end{array}$ & 0.08 & 2.58 & 0.95 \\
\hline
\end{tabular}

Source: The data in the table are based on the results of calculated functions.

Information given in column 2 of Table 1 showed that all calculated values are less than the critical value by the Kolmogorov-Smirnov test (0.174) at significant level equal 0.05. Data in column 3 are less than critical value of Pearson criterion (9.49). Data in column 4 exceed critical value 0.93 Shapiro-Wilk test with significant level of 0.01 . Thus, the computational experiment showed that all nine developed functions have high quality.

The density functions of the normal distribution (1)-(3) make it possible to identify a number of significant patterns that characterize the levels of solo entrepreneurship among 
REVISTA DE LA UNIVERSIDAD DEL ZULIA. 3época. Año $12 \mathrm{~N}^{\circ}$ 34, 2021

Iuliia Pinkovetskaia et al// Gender differences in solo entrepreneurship in modern countries, 224-238

DOI: $\underline{\text { http://dx.doi.org/10.46925//rdluz.34.14 }}$

women and men in the countries under consideration. The average values of the indicators are shown in column 2 of Table 2. Column 3 of the same table shows the intervals of change in the values of the indicators for most countries.

Table 2. Indicators that characterize the level of solo entrepreneurship for women and men

\begin{tabular}{|c|c|c|}
\hline Indicators & $\begin{array}{c}\text { Average } \\
\text { values }\end{array}$ & $\begin{array}{c}\text { Values typical for } \\
\text { most countries }\end{array}$ \\
\hline l & 2 & 3 \\
\hline $\begin{array}{c}\text { The share of solo entrepreneurs of women in the total } \\
\text { number of women who participate in the creation of }\end{array}$ & 0.33 & $0.14-0.52$ \\
\hline $\begin{array}{c}\text { The share of solo men entrepreneurs in the total } \\
\text { number of men who participate in the creation of their } \\
\text { own businesses in different countries }\end{array}$ & 0.27 & $0.12-0.42$ \\
\hline $\begin{array}{c}\text { The ratio of the values of indicators for solo } \\
\text { entrepreneurs to women and men }\end{array}$ & 1.38 & $0.76-2.00$ \\
\hline
\end{tabular}

Source: The author's calculations are based on functions (1)-(3).

The data shown in table 2 (column 2) show that, on average, in the countries under consideration, one third of new businesses were created in 2017-2018 by women who became solo entrepreneurs. At the same time, for most countries, the corresponding indicator was in the range from 0.14 to 0.52 . Slightly lower was the share of solo men entrepreneurs in the total number of men who participate in the creation of their own businesses, which was 0.27 .

In general, for men and women, the share of their participation in solo entrepreneurship was about 0.3 of the total number of the corresponding gender groups. Based on this, it can be assumed that about $70 \%$ of entrepreneurs chose legal entities as an organizational and legal form, that is, they were the owners of their own firms. Consequently, in modern national economies, entrepreneurs were more than twice as likely to create legal entities as those who were solo entrepreneurs. 
In most countries, the proportion of women who are solo entrepreneurs is higher than that of men who are solo entrepreneurs. The opposite trend was observed in 11 countries, namely Poland, Peru, Australia, Puerto Rico, Luxembourg, Iran, the United States, Mexico, Switzerland, Thailand and Panama. In five countries - Estonia, the Republic of Korea, Latvia, Slovenia, and Brazil - the share of men and women solo entrepreneurs in the respective populations is approximately equal. Average value of the ratio of the shares of solo indicators in the creation of new businesses for women and for men reaches 1.38.

To test hypothesis 1 on the differentiation of indicators by country, an analysis of the extent of variation of each of the indicators presented in table 2 was carried out. For this we used standard deviations. Variation indices are as follows: for the first indicator - 58\%, for the second indicator $-55 \%$, for the third indicator $-45 \%$. This analysis showed a significant differentiation of the values of each of the three indicators in the countries under consideration, that is, the hypothesis 1 was confirmed.

The next step was to identify the countries where the maximum and minimum values of each of the indicators were noted. Maximum values are those that exceed the upper limits of the ranges specified in column 3 of Table 2 , and the minimum values are those that are less than the lower limits of the specified ranges. The results of this analysis are shown in table 3 . Along with the lists of countries, this table also provides a division of the identified countries by their geographical location and income level.

Table 3 provides information on the geographical location of countries with high (column 2) and low (column 3) values for each of the three indicators evaluated in our study. The analysis of this information showed that there are no links between these values and the territorial location of the countries, as well as the level of income of the population in these countries. That is, both high and low values of indicators are observed in countries located in different parts of the world, as well as with different levels of income of the population. This allowed us to conclude that hypotheses 2 and 3 were confirmed.

It is of interest to study the data describing the values of the considered indicators in Russia:

- the value of the first indicator is 0.38 , which is $15 \%$ higher than the average value for other countries; 
REVISTA DE LA UNIVERSIDAD DEL ZULIA. 3época. Año $12 \mathrm{~N}^{\circ}$ 34, 2021

Iuliia Pinkovetskaia et al// Gender differences in solo entrepreneurship in modern countries, 224-238

DOI: $\underline{\text { http://dx.doi.org/10.46925//rdluz.34.14 }}$

Table 3. Countries with high and low indicator values

\begin{tabular}{|c|c|c|}
\hline icators & lues of in & alues of $i$ \\
\hline 1 & 2 & 3 \\
\hline $\begin{array}{c}\text { The share of solo } \\
\text { entrepreneurs of } \\
\text { women in the total } \\
\text { number of women } \\
\text { who participate in } \\
\text { the creation of their } \\
\text { own businesses }\end{array}$ & $\begin{array}{l}\text { Guatemala, Argentina, Spain, } \\
\text { Germany, Ecuador, the } \\
\text { Netherlands, } \\
\text { Sweden, Brazil. } \\
\text { Located in Europe (four } \\
\text { countries), Latin America (four } \\
\text { countries). } \\
\text { Income of the population: high } \\
\text { (four countries), medium (four } \\
\text { countries). }\end{array}$ & \begin{tabular}{|} 
Colombia, China, Mexico, \\
Qatar, Cyprus, Peru, Poland \\
Republic of Korea. \\
Located in Europe (two \\
countries), Asia (three \\
countries), Latin America \\
(three countries). \\
Income of the population: high \\
(four countries), medium (four \\
countries).
\end{tabular} \\
\hline $\begin{array}{c}\text { The share of solo } \\
\text { men entrepreneurs } \\
\text { in the total number } \\
\text { of men who } \\
\text { participate in the } \\
\text { creation of their } \\
\text { own businesses in } \\
\text { different countries }\end{array}$ & $\begin{array}{c}\text { Sweden, Estonia, Spain, } \\
\text { Netherlands, Panama, Argentina, } \\
\text { Ecuador, Brazil. } \\
\text { Located in Europe (four } \\
\text { countries), Latin America (four } \\
\text { countries). } \\
\text { The income of the population is } \\
\text { high (five countries), medium } \\
\text { (three countries). }\end{array}$ & $\begin{array}{c}\text { China, Qatar, Cyprus, } \\
\text { Egypt, Mexico, Bosnia and } \\
\text { Herzegovina, India, Bulgaria, } \\
\text { Malaysia. } \\
\text { Located in Europe (three } \\
\text { countries), Asia (four } \\
\text { countries), Africa (one } \\
\text { country). } \\
\text { Income of the population: high } \\
\text { (two countries), medium (five } \\
\text { countries), low (two } \\
\text { countries). }\end{array}$ \\
\hline $\begin{array}{c}\text { The ratio of the } \\
\text { values of indicators } \\
\text { for solo } \\
\text { entrepreneurs to } \\
\text { women and men }\end{array}$ & $\begin{array}{c}\text { China, Germany, } \\
\text { Bosnia and Herzegovina, Bulgaria } \\
\text { Egypt, Qatar, Taiwan. Located in } \\
\text { Europe (three countries), Asia } \\
\text { (three countries), Africa (one } \\
\text { country). Income of the } \\
\text { population: high (three } \\
\text { countries), medium (three } \\
\text { countries), low (one country). }\end{array}$ & $\begin{array}{l}\text { Colombia, Poland, Peru, } \\
\text { Australia, Puerto Rico } \\
\text { Luxembourg. } \\
\text { Located in Europe (two } \\
\text { countries), Australia (one } \\
\text { country), Latin America (three } \\
\text { countries). } \\
\text { The income of the population is } \\
\text { high (four countries), medium } \\
\text { (two countries), low (two } \\
\text { countries). }\end{array}$ \\
\hline
\end{tabular}

Source: Developed by the author on the basis of data from Table 2 and the Global Entrepreneurship Monitoring project. 


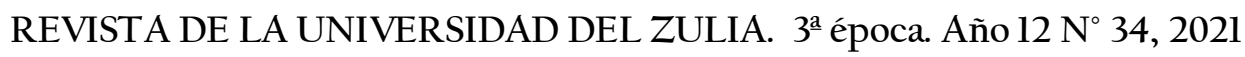

Iuliia Pinkovetskaia et al// Gender differences in solo entrepreneurship in modern countries, 224-238

DOI: $\underline{\text { http://dx.doi.org/10.46925//rdluz.34.14 }}$

- the value of the second indicator is 0.32 , which is $18 \%$ higher than the average value for other countries;

- the value of the third indicator is 1.20 , which is $13 \%$ lower than the average value for other countries.

The analysis showed that the level of solo entrepreneurship in Russia is higher than the average in other countries. In addition, the trend of women's greater propensity for solo entrepreneurship in comparison with men, which is typical for most countries, was confirmed in Russia.

\section{Conclusion}

The goal of the study, namely, to assess the indicators describing the level of solo entrepreneurship in the total number of women and men who are beginning entrepreneurs in different countries, was achieved. The conclusions of the study, which contain scientific novelty and originality, include:

1. An assessment of the indicators characterizing the share of men and women involved in solo entrepreneurship, respectively, in the total number of men and women starting their own new businesses in different countries was carried out.

2. The distribution of three indicators describing solo entrepreneurship in 59 countries was modeled.

3. It is shown that solo entrepreneurship has received significant development in most modern national economies

4. It is proved that entrepreneurs often create legal entities for conducting their business, than they are solo entrepreneurs.

5. It is proved that the share of women involved in solo entrepreneurship is higher in most countries compared to the same indicator for men.

6. It is shown that in most countries there are gender differences for each of the three indicators.

7. The average values of each of the three indicators under consideration are established, as well as the intervals of their change that are typical for most countries.

8. It shows that there are significant differences in the values of the three indicators considered by country. 
REVISTA DE LA UNIVERSIDAD DEL ZULIA. 3época. Año $12 \mathrm{~N}^{\circ}$ 34, 2021

Iuliia Pinkovetskaia et al// Gender differences in solo entrepreneurship in modern countries, 224-238 DOI: $\underline{\text { http://dx.doi.org/10.46925//rdluz.34.14 }}$

9. Countries with high and low values of each of the three indicators are presented.

10. A comparison of the values of indicators for Russia and other countries was carried out.

The results obtained are of theoretical and practical significance for governments and entrepreneurs. The methodological approach to the assessment of gender differences in solo entrepreneurship presented in the article can be applied in further research. The new knowledge gained is of interest and can be used in the educational process at universities.

The study had limitations on empirical data due to the fact that only 59 countries were considered.

\section{References}

Abraham K., Amaya A. (2019). Probing for Informal Work Activity. Journal of Official Statistics, 35, 487-508. DOI: 10.2478/jos-2019-0021.

Boeri T., Giupponi G., Krueger A.B., Machin S. (2020). Solo Self-Employment and Alternative Work Arrangements. The Journal of Economic Perspectives, 34(1), 170-195. DOI: $10.1257 /$ jep.34.1.170.

Bogenhold D. (2019). From hybrid entrepreneurs to entrepreneurial billionaires: Observations on the socio-economic heterogeneity of self-employment. American Behavioral Scientist, 63(2), 129-146. DOI: 10.1177/0002764218794231.

Box M., Segerlind T.L. (2018). Entrepreneurial Teams, Gender, and New Venture Survival: Contexts and Institutions. SAGE Open. Special Collection - Entrepreneurial Teams, AprilJune, 1-17. DOI: 10.1177/2158244018777020.

Cowling M. (2000). Are entrepreneurs different across countries? Applied Economics Letters, 7(12), 785-789. DOI: 10.1080/135048500444804.

Dvoulety O., Prochazka D.A., Starnawska M. (2019). Who earns more: job creators, soloentrepreneurs or employees? Empirical evidence from Visegrad countries. International Journal of Entrepreneurship and Small Business, 1(1), 1-12. DOI: 10.1504/IJESB.2019.10020600.

Fritsch M., Wyrwich M. (2014). The long persistence of regional levels ofentrepreneurship: Germany, 1925-2005. Regional Studies, 48, 955-973. DOI: 10.1080/00343404.2013.816414.

Giupponi G., Xu X. (2020). What Does the Rise of Self-Employment Tell Us About the UK Labour Market? London, Institute of Fiscal Studies. 
Global Entrepreneurship Monitor 2018/2019 Women's Entrepreneurship Report (2019). Global Entrepreneurship Research Association (GERA). London Business School, London, United Kingdom.

Gottschalk S., Niefert M. (2013). Gender differences in business success of German start-up firms. International Journal of Entrepreneurship and Small Business, 18, 15-46. DOI: 10.2139/ssrn.1795228.

Gudmunson C.G., Danes S.M., Werbel J.D., Loy J.T., Teik-Cheok J. (2009). Spousal Support and Work-Family Balance in Launching a Family Business. Journal of Family Issues, 30(8), 1098-1121. DOI: 10.1177/0192513X09333758.

Hipp L., Bernhardt J., Allmendinger J. (2015). Institutions and the prevalence of nonstandard employment. Socio-Economic Review, 13(2), 351-377. DOI: $10.1093 / \mathrm{ser} / \mathrm{mwv} 002$.

Holloway S., Pimlott-Wilson H. (2021). Solo self-employment, entrepreneurial subjectivity and the security-precarity continuum: Evidence from private tutors in the supplementary education industry. Environment and Planning A: Economy and Space, April 29, 1-18. DOI: $10.1177 / 0308518 \times 211009237$.

Katz L., Krueger A. (2018). The Rise and Nature of Alternative Work Arrangements in the United States, 1995-2015. Industrial and Labor Relations Review, 72(2), 382-416. DOI: 10.1177/0019793918820008.

Koe W.-L. (2016). The relationship between Solo Entrepreneurial Orientation (IEO) and entrepreneurial intention. Journal of Global Entrepreneurship Research, 6(13). DOI: 10.1186/s40497-016-0057-8.

Lee N., Rodnguez-Pose A. (2021). Entrepreneurship and the fight against poverty in US cities. Environment and Planning A, 53(1), 31-52. DOI: 10.1177/0308518X20924422.

Mababu R. (2009). Entrepreneur's behavior: Approach to Personal Characteristics of Entrepreneurs in Small and middle sided Businesses. Revista CEF de Trabajo y Seguridad Social, 324, 131-164.

Mababu R., Merino-Hijosa A. (2015). Solo-entrepreneurs and Motivation of Business Development in Technology Industry. The International Journal of Business \& Management, 3(12), 202-210.

Millan J.M., Congregado E., Roman C. (2012). Determinants of self-employment survival in Europe. Small Business Economics, 38, 231-258. DOI: 10.1007/sll187-010-9260-0.

Pinkovetskaia I., Nuretdinova Y., Nuretdinov I., Lipatova N. (2021). Mathematical modeling on the base of functions density of normal distribution. Revista de la Universidad del Zulia. $3^{\text {a }}$ época. Año 12, 33, 34-49. DOI: 10.46925//rdluz.33.04. 
Pinkovetskaia I., Schennikova N., Kryukova L. (2020). Individual entrepreneurship in Russia: measuring data of 2018. Revista Inclusiones, 7, Especial- OCTUBRE/DICIEMBRE, 668-679.

Ruzzier M., Konecnik Ruzzier M. (2015). On the relationship between firm size, resources, age at entry and internationalization: the case of Slovenian SMEs. Journal of Business Economics and Management, 16(1), 52-73. DOI: 10.3846/16111699.2012.745812.

Schneck S. (2020). Self-employment as a source of income inequality. Eurasian Business Review, 10(1), 45-64. DOI: 10.1007/s40821-019-00143-8.

Schummer S.E., Kathleen O., Hunefeld L., Kottwitz M. (2019). The role of need satisfaction for solo self-employed solos' vs. employer entrepreneurs' affective commitment towards their own businesses. Journal of Global Entrepreneurship Research, 9(63), 1-18. DOI: 10.1186/s40497-019-0190-2.

Szerb L., Lafuente E., Horvath K., Pager B. (2019). The relevance of quantity and quality entrepreneurship for regional performance: The moderating role of the entrepreneurial ecosystem. Regional Studies, 53(9), 1308-1320. DOI: 10.1080/00343404.2018.1510481.

Toivanen S., Mellner C., Vinberg S. (2015). Self-Employed Persons in Sweden - Mortality Differentials by Industrial Sector and Enterprise Legal Form: A Five-Year Follow-Up Study. American Journal of Industrial Medicine, 58(1), 21-32. DOI: 10.1002/ajim.22387.

Van Gelderen M., Jansen P. (2006). Autonomy as a start-up motive. Journal of Small Bussiness and Enterprise Development, 13(1), 23-32. DOI: 10.1108/14626000610645289.

Van Stel A., Kaciak E., Cieślikb J. (2020). Hiring plans by solo entrepreneurs at the time of start-up: The role of education and the desire for self-expression. Journal of Business Research, 119, October, 58-66. DOI: 10.1016/j.jbusres.2020.06.060.

Van Stel A., Van der Zwan P. (2020). Analyzing the changing education distributions of solo self-employed workers and employer entrepreneurs in Europe. Small Business Economics, 55, 429-445. DOI: 10.1007/s1l187-019-00243-9.

Vries N., Liebregts W., Van Stel A. (2020). Explaining entrepreneurial performance of solo self-employed from a motivational perspective. Small Business Economics, 55, 447-460. DOI: $10.1007 /$ sll187-019-00244-8.

Yang T., Del Carmen, Triana M. (2017). Set up to fail: Explaining when women-led businesses are more likely to fail. Journal of Management, 45(3), 926-954. DOI: 10.1177/0149206316685856. 